\title{
Turist Rehberi Adaylarının Uygulama Gezilerinden Beklentilerinin ve Memnuniyet Düzeylerinin Araştırılması
}

\section{Investigation of Tourist Guide Candidates' Expectations and Satisfaction Levels from the Training Tours}

\author{
Ali MANAV \\ Afyon Kocatepe Üniversitesi, Sosyal Bilimler Enstitüsü, Türkiye \\ Afyon Kocatepe University, Graduate School of Social Sciences, Turkey \\ E-Mail: alim.nv@gmail.com
}

Doç. Dr Hasan Hüseyin SOYBALI

Afyon Kocatepe Üniversitesi, Turizm Fakültesi, Türkiye Afyon Kocatepe University, Tourism Faculty, Turkey

E-Mail: hsoybali@aku.edu.tr

$\ddot{O} \mathbf{z}$

Amaç ve Önem: Bu çalışmanın amacı, turist rehberi adaylarının uygulama gezilerinden beklentilerini ve memnuniyet düzeylerini araştırmaktır. Bu amaçla öncelikle turist rehberliği ile ilgili literatür taraması yapılmıştır. Daha sonra turist rehberi olmak için gerekli şartlar irdelenmiştir. Bu şartlardan biri olan uygulama gezileri çalışmanın temelini oluşturmaktadır.

Yöntem: Turist rehberi adaylarının uygulama gezilerinden beklentilerinin ve memnuniyet düzeylerinin belirlenmesi amacıyla Ocak-Şubat 2019 aylarında gerçekleştirilen uygulama gezilerine katılan önlisans, lisans ve yüksek lisans düzeyinde öğrenim gören turist rehberliği öğrencilerine anket uygulanmıştır.

Bulgular: Katılımcıların yaşadıkları ülkeyi gezme arzusunda olsalar dahi gezi süresinin uzunluğunun motivasyon kaybına yol açtığı sonucuna ulaşılmıştır. Araştırmadan elde edilen bulgular, bu gezilere katılanların beklentilerinin yüksek ancak memnuniyet düzeylerinin düşük olduğunu, dolayısıyla istenilen düzeyde iyi hizmet alınamadığını ortaya koymuştur. Bu sebeple geziden beklenen verimin alınamadığı ve amacına ulaşamadığı tespit edilmiştir.

Özgünlük/Bilimsel Katkı: Çalışmada, Ocak 2019-Şubat 2019 tarihleri arasında gerçekleştirilen uygulama gezisine katılan önlisans, lisans ve yüksek lisans düzeyinde öğrenim gören turist rehberliği öğrencilerinin uygulama gezilerinden beklenti ve memnuniyet düzeyleri incelenmiştir. Literatürde konuyla ilgili çok az çalışmaya rastlanmıştır. Bu doğrultuda, bu çalışmanın ilgili literatüre katkı sağlayacağı düşünülmektedir.

Çalışmanın Sınırlılıkları: Araştırma Ocak-Şubat 2019 tarihlerinde gerçekleştirilen uygulama gezisine katılan önlisans, lisans ve yüksek lisans düzeyinde öğrenim gören turist rehberliği öğrencilerinin sorulara verdiği cevaplarla sinırlıdır.

Anahtar Kelimeler: Turist rehberi, uygulama gezileri, beklenti, memnuniyet düzeyi.

Makale Türü: Araştırma makalesi

\section{Abstract}

Purpose and Importance: The purpose of this study is to investigate the expectation and satisfaction levels of the tourist guide candidates from the training tours. For this purpose, firstly a literature review related to tourist guidance has been carried out. Then the necessary conditions for being a tourist guide

Atıf için (for cited); Manav, A. ve Soybalı, H. H. (2020). Turist Rehberi Adaylarının Uygulama Gezilerinden Beklentilerinin ve Memnuniyet Düzeylerinin Araştırılması, Turist Rehberliği Dergisi, 3(1),18-31. 
Turist Rehberliği Dergisi (TURED) \& Yıl. 2020, Cilt. 3, Sayı. 1

Journal of Tour Guiding (JOTOG) \& Year. 2020, Volume. 3, Issue. 1

were examined. Training tours, one of these conditions, form the basis of the study. The training tours are a long-term tour where the theoretical knowledge of the students who want to be a tourist guide is put into practice.

Methodology: In order to determine the expectations and satisfaction levels of the tourist guides candidates from the training tours, a questionnaire was applied to the tourist guidance students who attended the training tour held in January-February 2019, studying at the associate degree, undergraduate and post graduate levels.

Findings: Even if the participants want to know better the country they live in, the length of the tour time leads to a loss of participant motivation. The results of the research revealed that the expectations of the participants were high but the satisfaction levels were low and therefore the desired level of service could not be obtained. Therefore, it is determined that the expected efficiency of the training tours was not achieved and reached its expected goals.

Originality/Value: In the study, the expectations and satisfaction levels of the tourist guidance students who attended the training tour held between January 2019 and February 2019 were examined from the training tour. Few studies have been found on the subject in the literature. In this context, it is expected to contribute to the literature on this study.

Research Limitations/ Implications: The research is limited with the answers given by the tourist guide candidates who participated in the training tour held in January-February 2019.

Keywords: Tourist guide, training tour, expectations, satisfaction level.

Paper Type: Research article

Giriş

Turizm farklı bir yerden gelen kişilerin geçici şekilde bir yerde bulunması neticesinde ortaya çıkan iktisadi eylemlerdir. Turizm, oluşturduğu ekonomiyle ülkelerin gelişmesinde önemli bir rol oynamaktadır. Turizmin yapıldığı coğrafyanın nitelikleri ve kültür ile tarihi dokuları sebebiyle coğrafya ile turizm etkileşim halindedir. Ayrıca turizm, çeşitli sosyal ve kültürel oluşumlara ev sahipliği yapan toplumların birbirleriyle iletişimde olmasına, çeşitli bilgi, görgü, kültür ve gelenek seviyeleri arasındaki etkileşime ve bunların neticesinde toplumsal yapının etik anlayışının ve sosyal tutumların farklılaşmasına sebep olan toplumsal bir durumdur. Bunun yanı sıra, kişilerin psikolojik açıdan rahat olma, memnuniyet ve tatmin olma amaçları turizm eylemlerinin gerçekleşme nedenine 1şık tutmaktadır.

Turizm faaliyetleri sırasında turist rehberleri vazgeçilmez bir unsurdur. Bu mesleğin kökleri antik çağlara kadar uzanmaktadır. Ülkemizde de bu mesleğin Osmanlı döneminden başlayarak günümüze kadar birçok zorluk ve yasal süreçlerden geçerek şu anki şeklini aldığı görülmektedir. Bu mesleği icra edenler bir öğretmen edasıyla çevresiyle ilgili doğru bilgiler vermek, turistlerin beklentilerini gerçekleştirmek, iyi bir gezi tecrübesi vaat etmek, pazarlama ve satış çalışmalarını ekstra tur satışı, hediyelik eşya ve eğlence sahalarında yaparak ekonomiye katk1 sağlamak gibi görevlerle yükümlüdürler. Turist rehberliğini meslek edinmek isteyen kişiler, bilgi birikim düzeyleri yüksek ve okumayı seven kişiler olmalıdır. Fiziki güce dayanması özellikle gençlerin bu mesleği seçmesinde önemli rol oynamıştır. Turist rehberliğinin birçok problemi de bulunmaktadır. Bunlara örnek olarak emeklilik yaşının ya çok yüksek ya da hiç olmaması, sürekli ayakta kalma durumu ve en ufak bir sorunun gezi programında aksamalara neden olması durumları örnek olarak verilebilir.

Turist rehberliği mesleğini edinmek için de bir eğitim almak mecburidir. Turist rehberi olabilmek için Kültür ve Turizm Bakanlığı tarafindan verilen sertifika programlarından başarılı olmak ya da üniversitelerin önlisans veya lisans düzeyinde turizm rehberliği eğitimi

Manav ve Soybali; Turist Rehberi Adaylarının Uygulama Gezilerinden Beklentilerinin ve Memnuniyet

Düzeylerinin Araştırılması / Investigation of Tourist Guide Candidates' Expectations and Satisfaction Levels from the Training Tours 


\section{IIIII)}

Turist Rehberliği Dergisi (TURED) \& Yıl. 2020, Cilt. 3, Sayı. 1

Journal of Tour Guiding (JOTOG) \& Year. 2020, Volume. 3, Issue. 1

alınması gerekmektedir. Ayrıca 45 gün süren uygulama gezisine katılmak ve yabancı dil koşulunu yerine getirme şartı da bulunmaktadır. Bu çalışmada öncelikle turizmin tanımı, farklı alanlarla olan ilişkileri ele alınmış daha sonra turist rehberliğinin tarihsel gelişiminden başlanarak bu mesleğe dair özellikler ve turist rehberlerinin özellikleri, yaşadıkları sorunlar, turizmdeki önemleri, yaşam kaliteleri ve bu mesleği edinmenin koşullarından bahsedilmiştir.

\section{Turist Rehberliği}

Turist rehberleri, gezilen destinasyonun algısı açısından büyük bir etkiye sahiptir. Rehberin, turistin gezilen bölgeye ilişkin sahip olduğu önyargıları yıkma ve algılarını değiştirme gibi bir etkisi olmaktadır. Turist rehberinin destinasyon için pozitif bir etki oluşturması sonucunda turistin bu destinasyonu tavsiye etme olasıllğı artacağı gibi bu bölgeyi tekrar ziyaret etmeye de eğilimi olacaktır. Turistlere doğru bilgiler aktarmak, rehberin en önemli görevidir. Rehberin turistlere bir destinasyonun tarihini, kültürünü ve coğrafi önemini anlatması turist rehberlerinin yükümlülükleri arasında yer almaktadır. Turist rehberleri turistlere bilgi verirken genelde öğretmenlik rolüne bürünmektedir. Turist rehberi yalnızca turiste bilgi vermekle yükümlü değildir. Turist kitlesinin beklentilerini olabildiğince yerine getirerek rehberlik gezisinden keyif almalarını ve memnun ayrılmalarını sağlamalıdır (Güzel, 2007: 31).

Profesyonel turist rehberliği meslek olarak kendine özgü nitelikleri sebebi ile derin bir bilgi birikimine sahip olmayı öngörmektedir. Turist rehberleri, diğer mesleklerden ayrı olarak herhangi bir seyahat acentesine bağımlı bir şekilde tam zamanlı çalışmayı gerektirmemektedir (Arslantürk, 2016: 193). 2012 senesinde yürürlüğe konan 6326 sayılı Turist Rehberliği Meslek Kanunu ve sonrasında güncellenen yönetmelikle tam zamanlı çalışma için hukuki bir zemin hazırlansa dahi bu durumun son haline ilişkin bir bilgi bulunmamaktadır. Rehberlik mesleği, kapsamı gereği uzun saatler ayakta kalmayı ve düzensiz bir yaşamı gerektirmektedir. Rehberler, tur süresince gerek otobüste gerekse de gezilen yerlerde sürekli hareket ederler. Aynı zamanda, kesin çizgilerle belirlenmiş çalışma saatleri bulunmamaktadır, bu nedenle de düzensiz uykuları vardır (Köroğlu, 2011: 252).

Bütün disiplinlerde olduğu gibi turist rehberliğinde de eğitim almak şarttır. Daha önceki senelerde bu eğitimi Kültür ve Turizm Bakanlığı açtı̆̆ 1 kurslarla sağlamaktaydı (Çolakoğlu vd., 2010). 1970'li senelerden başlayarak üniversite seviyesinde verilen turizm eğitimi, 1990'lı senelerden sonra farklı branşlar altında çalışılmıştır (Ahipaşaoğlu, 2001: 36). Turizm eğitimi ile ilgili eğitim sistemi incelendiğinde, Kültür ve Turizm Bakanlığ tarafindan verilen kurslar, üniversiteler bünyesinde ön lisans ve lisans programı olacak şekilde üç tür rehberlik eğitim sistemi olduğu görülmektedir. Bakanlık tarafınca yedi aylık eğitim, 2005 senesinde çıkarılan yönetmeliğe kadar geçen sürede ulusal ve bölgesel olmak kaydıyla iki seviyede yürütülmüştür (Kozak, 2009: 1-2). Rehber olabilmek için yalnızca bu derslerden başarılı olmak yeterli değildir; 45 gün süren uygulamalı Türkiye gezisine katılmak ve dil yeterliliğini sağlamak gerekmektedir. Üniversitedeki bölümlerde turist rehberliği alıp derslerin \%75'ini başarı ile geçen öğrenciler, mezun olmadan önce uygulama gezisine katılma hakkı kazanırlar (Çolakoğlu vd., 2010: 192). Eğitimini yaygın veya örgün eğitim olarak görüp görmediği fark etmeksizin çalışma kartı almak isteyen tüm rehber adaylarının dil yeterliliği ve uygulama gezi şartlarını yerine getirmelidir.

\section{Turist Rehberliği Uygulama Gezileri}

Uygulama gezileri yerel sertifika programları adına birer birer organize edilmektedir. Ülke genelindeki yurtiçi gezilerin süresi en az 36 gün, yöresel yurtiçi gezilerinin süresiyse her bölge adına en az 6 gündür. Ülke genelindeki uygulama gezilerinin Birlik tarafindan 
Turist Rehberliği Dergisi (TURED) \& Yıl. 2020, Cilt. 3, Sayı. 1

Journal of Tour Guiding (JOTOG) \& Year. 2020, Volume. 3, Issue. 1

yapılmasının icap edildiği durumlarda kısımlara ayrılarak gerçekleştirilebilmektedir. Uygulama gezilerinin hepsine dâhil olarak diğer koşulları gerçekleştiren katılımcılar Ülkesel Turist Rehberi; bu gezileri bölge bazında tamamlayıp diğer şartları da gerçekleştiren katılımcılarsa muvaffak oldukları bölgeler adına Bölgesel Turist Rehberi sıfatını elde etme hakkına sahip olurlar (PTR Yönetmelik, 2014: madde 14).

Rehberlik uygulama gezisi, turist rehberliği eğitimine katılmış olanların turist rehberi olabilmeleri adına gerçekleştirmek zorunda oldukları şartlardan bir tanesidir ve öğrencilerin görmüş oldukları teorik dersleri uygulamaya geçirdikleri mühim bir programdır. Uygulama gezileri, öğrencilerin turist rehberi olmadan önce yerine getirdikleri ilk aşama ve ilk tecrübe olması bakımından oldukça önemli bulunmakta ve katılımcılar turist rehberliğinin nasıl tatbik edildiğini aktif bir şekilde öğrenmektedirler. Bunun yanı sıra öğrenciler, eğitimin içerisindeki uygulama gezisi sırasında kendi meslekleriyle alakalı kullanışlı bilgiler elde ederken diğer yandan bir turist perspektifiyle turda gerçekleşen durumlara da yakından tanık olabilmektedirler. Turist rehberlerinin, kaliteli bir eğitim görmenin dışında liderlik, tahammül, duyarlılık, espri kabiliyeti, kararlılık gibi birtakım kişisel nitelikleri de barındırması gerekir. Turist rehberliği yurtiçi uygulama gezisi, katılımcıların bu kişisel niteliklerin hangisinden yoksun veya hangisine eğilimli olduğunu anlamalarında da rol oynamaktadır (Erdem ve Etiz, 2012). Uygulama gezisinde verilen derslerle, turist rehberinin turizm alanı ve işiyle alakalı her hususta bilgili olması hedeflenmektedir. Doğal olarak, turist rehberliği eğitiminde akademik eğitimin dışında uygulama yapma imkânı bulunan yurtiçi uygulama gezileri oldukça önemlidir.

\section{Araştırmanın Amacı ve Önemi}

$\mathrm{Bu}$ araştırmanın amacı, turist rehberi adaylarının uygulama gezisinden beklenti ve memnuniyet düzeylerinin ortaya konmasıdır. Literatür taraması yapıldığında uygulama gezileriyle ilgili yapılan farklı çalışmaların olduğu görülmüss, ancak rehber adaylarının uygulama gezileri hakkında çok sınırlı sayıda çalışma bulunduğu anlaşılmıştır. Bu açıdan, çalışmanın ilgili literatüre katkı sağlayama açısından önem taşıdığı düşünülmektedir. $\mathrm{Bu}$ kapsamda, turist rehberi adaylarını uygulama gezisinden beklenti ve memnuniyet düzeylerinin belirlenmesi amaçlanmaktadır. $\mathrm{Bu}$ doğrultuda araştırmada şu sorulara yanıt aranmıştır:

1. Turist rehberi adaylarının uygulama gezisine yönelik beklentileri ne düzeydedir?

2. Turist rehberi adaylarının uygulama gezisine yönelik memnuniyetleri ne düzeydedir?

3. Turist rehberi adaylarının uygulama gezisine yönelik beklenti ve memnuniyet düzeyleri demografik özellikleri göre farklılık göstermekte midir?

4. Turist rehberi adaylarının uygulama gezisine yönelik beklenti ve memnuniyet düzeyleri arasında anlamlı bir farklılık var mıdır?

\section{Yöntem}

Araştırmada öncelikle turist rehberlerinin uygulama gezilerinden beklenti ve memnuniyet düzeyleriyle ilgili literatür taraması yapılmıştır. Araştırmanın evrenini üniversitelerin Turizm/Turist Rehberliği bölümlerinde önlisans, lisans ve yüksek lisans eğitimi alan ve uygulama gezilerine katılan öğrenciler oluşturmaktadır. Anket uygulanan kış döneminde uygulama gezilerine her grupta yaklaşı 250 adayın bulunduğu dört grupta yaklaşık 1000 aday katılmıştır. Anket verileri Ocak ve Şubat 2019 ayları arasında gerçekleştirilen uygulama gezisine katılan 47 katılımcıdan elde edilmiştir. Uygulama aşamasında veri toplama yöntemlerinden anket tekniğinden yararlanılmıştır. Katılımcılara, uygulama gezisi organizasyonu ve hizmetlerinden, ulaşım hizmetlerinden, Konaklama/yeme-

Manav ve Soybalı; Turist Rehberi Adaylarının Uygulama Gezilerinden Beklentilerinin ve Memnuniyet

Düzeylerinin Araştırılması / Investigation of Tourist Guide Candidates' Expectations and Satisfaction Levels from the Training Tours 
Turist Rehberliği Dergisi (TURED) \& Yıl. 2020, Cilt. 3, Sayı. 1

Journal of Tour Guiding (JOTOG) \& Year. 2020, Volume. 3, Issue. 1

içme/otel hizmetlerinden ve rehberlik hizmetlerinden beklenti memnuniyet düzeylerini belirlemeye yönelik sorular sorulmuștur. Anket formu temel olarak iki bölümden oluşmaktadır. Formun ilk bölümünde katılımcılara ait bazı demografik unsurlara, ikinci bölümde katılımcıların uygulama gezilerinden beklenti ve memnuniyet düzeylerine ilişkin derecelendirmeli 53 ifadeye yer verilmiştir. İfadelerin oluşturulmasında ilgili literatürden faydalanılmış, 5'li Likert tipi ölçek kullanılmıştır.

Araştırma verilerinin analizinde temel olarak sıklık ve yüzde analizleri, aritmetik ortalama ve standart sapma tekniklerinden faydalanılmıştır. Bu kapsamda demografik ve mesleki değişkenlerin elde edilmesini amaçlayan soruların analizinde sıklık ve yüzde analizleri ile katılımcılara ait temel bilgiler elde edilmiştir. Uygulama gezilerine ilişkin beklenti ve memnuniyet düzeylerinin belirlenmesi amaciyla oluşturulan ölçekte yer alan ifadelerin ölçümünde ise aritmetik ortalama ve standart sapma teknikleri ile katılımcı görüşlerinin bireysel özelliklere göre karşılaştırılmasında iki gruba ait olan ortalamaların birbirinden farklı olup olmadığını test etmek amacıyla kullanılan $t$ testi (Independent Samples t test) kullanılmışırır.

\section{Bulgular}

Katılımcıların demografik özelliklerine ilişkin bilgiler Tablo 1'de yüzde ve frekans analizleriyle verilmiştir. Çalışmaya katılanların demografik özellikleri incelendiğinde, katılımcıların \%21,3'ü kadın, \%78,7'si erkek olduğu tespit edilmiştir. Katılımcıların medeni durumları incelendiğinde, \%63,8'inin bekâr, \%36,2'sinin evli olduğu tespit edilmiştir. Katılımcıların yaş aralıkları incelendiğinde, \%74,5'inin 18-34 yaş aralığında, \%25,5'inin 3554 yaş aralığında olduğu belirlenmiştir.

Tablo 1. Katılımcıların Demografik Özelliklerine İlişkin Bulgular

\begin{tabular}{|l|c|c|c|}
\hline \multicolumn{2}{|c|}{} & f & \% \\
\hline \multirow{2}{*}{ Cinsiyet } & Kadın & 10 & 21,3 \\
\cline { 2 - 4 } & Erkek & 37 & 78,7 \\
\hline \multirow{2}{*}{ Medeni Durum } & Bekâr & 30 & 63,8 \\
\hline \multirow{2}{*}{ Yaş } & Evli & 17 & 36,2 \\
\cline { 2 - 4 } & $18-34$ & 35 & 74,5 \\
\cline { 2 - 4 } & $35-54$ & 12 & 25,5 \\
\hline
\end{tabular}

Tablo 2'de katılımcıların beklenti düzeylerine ilişkin görüşleri yer almaktadır. Tablo 2'deki görüşlere göre, uygulama gezisi organizasyonu ve hizmetlerinden beklenti boyutundaki "Tur programının iyi organize edilmiş olmasını beklerim" ifadesi $(X=4,65)$ bu boyuttaki en yüksek ortalamaya sahip ifade olmuştur. Uygulama gezisi organizasyonu ve hizmetlerinden beklenti boyutundaki en düşük ortalamaya sahip ifade ise "Uygulama gezisi ücret ödemesinin taksitli olmasını beklerim" ifadesi $(X=4,36)$ ve "Uygulama gezisi başvuru işlemlerinin kolay yapılabilmesini beklerim" ifadesi $(\mathrm{X}=4,36)$ olmuştur. Verilen cevaplardan, uygulama gezisine katılan kişilerin, tur programı ile ilgili beklentilerinin fazla olduğu ifade edilebilir. Aynı zamanda, uygulama gezisi başvuru işlemlerinde zorlandıkları ve uygulama gezisi ücret ödemelerinin taksitli olmadığı sonucu çıkarılabilir.

Ulaşım hizmetlerinden beklenti boyutunda yer alan "Aracın klimasının çalışmasını beklerim" ifadesi $(X=4,70)$ bu boyuttaki en yüksek ortalamaya sahip olan ifade olmuştur. $\mathrm{Bu}$ boyuttaki en düşük ortalamaya sahip olan ifade ise "Araçta içecek servisi yapılmasını beklerim" ifadesi $(X=4,02)$ olmuştur. Verilen cevaplardan, araç içerisinde içecek servisi yapılmadığı ya da çok az yapıldığı anlaşılabilir. 
Turist Rehberliği Dergisi (TURED) \& Yıl. 2020, Cilt. 3, Sayı. 1

Journal of Tour Guiding (JOTOG) \& Year. 2020, Volume. 3, Issue. 1

Tablo 2: Katılımcıların Beklenti Düzeylerine İlişkin Görüşleri

\begin{tabular}{|c|c|c|c|}
\hline & & $\mathbf{X}$ & SS \\
\hline \multirow{9}{*}{ 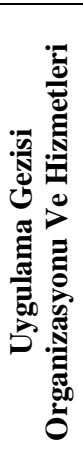 } & Tur programının iyi organize edilmiş olmasını beklerim. & 4,65 & 0,86 \\
\hline & $\begin{array}{l}\text { Acentanın zimmetimize verdiği headset ve kulaklıkların düzgün çalışmasını } \\
\text { beklerim. }\end{array}$ & 4,63 & 0,89 \\
\hline & Turun yeni şeyler öğrenmemi sağlamasını beklerim. & 4,59 & 0,90 \\
\hline & Uygulama gezisi ücretinin pahalı olmamasını beklerim. & 4,59 & 0,92 \\
\hline & Tura başlamadan önce genel olarak turla ilgili bilgi verilmesini beklerim. & 4,55 & 0,87 \\
\hline & $\begin{array}{l}\text { Tura başlamadan önce ziyaret edeceğimiz yerler hakkında bilgi verilmesini } \\
\text { beklerim. }\end{array}$ & 4,48 & 0,95 \\
\hline & $\begin{array}{l}\text { Tura başlamadan önce uygulanması gereken kurallar hakkında bilgi verilmesini } \\
\text { beklerim. }\end{array}$ & 4,40 & 0,97 \\
\hline & Uygulama gezisi ücret ödemesinin taksitli olmasını beklerim. & 4,36 & 0,96 \\
\hline & Uygulama gezisi başvuru işlemlerinin kolay yapılabilmesini beklerim. & 4,36 & 0,96 \\
\hline \multirow{11}{*}{ 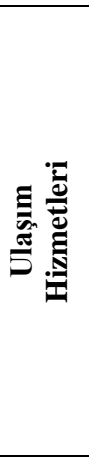 } & Aracın klimasının çalışmasını beklerim. & 4,70 & 0,85 \\
\hline & Araçta iki tane şoför olmasını beklerim. & 4,51 & 0,97 \\
\hline & Otobüs şoförlerinin yolu bilmelerini beklerim. & 4,51 & 0,90 \\
\hline & $\begin{array}{l}\text { Araçta telefon, tablet vb. Aletleri şarj edebilmek için araç prizlerinin çalışmasını } \\
\text { beklerim. }\end{array}$ & 4,48 & 1,03 \\
\hline & Aracın içinin ve dışının temiz olmasını beklerim. & 4,48 & 1,01 \\
\hline & Otobüs şoförlerinin sabırlı olmasını beklerim. & 4,46 & 0,88 \\
\hline & Tur boyunca yapılacak yolculukların konforlu olmasını beklerim. & 4,46 & 0,99 \\
\hline & Otobüs şoförlerinin güler yüzlü olmalarını beklerim. & 4,31 & 1,00 \\
\hline & Tur için kullanılacak aracın beş yaşından büyük olmamasını beklerim. & 4,25 & 1,07 \\
\hline & Araçta bir tane muavin olmasını beklerim. & 4,04 & 1,16 \\
\hline & Araçta içecek servisi yapılmasını beklerim. & 4,02 & 1,32 \\
\hline \multirow{16}{*}{ 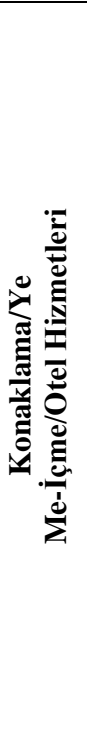 } & Turda yapılacak konaklamalar için seçilen otellerin temiz olmasını beklerim. & 4,68 & 0,88 \\
\hline & $\begin{array}{l}\text { Konaklanacak otel odalarındaki banyoların ve tuvaletlerin hijyenik olmasını } \\
\text { beklerim. }\end{array}$ & 4,61 & 0,87 \\
\hline & Otellerde verilen yemeklerin ve yemek hizmetlerinin iyi olmasını beklerim. & 4,59 & 0,87 \\
\hline & Odalarda internet kullanımının ücretsiz olmasını beklerim. & 4,57 & 0,92 \\
\hline & Konaklanacak otellerde çamaşır yıkama ve ütüleme hizmetinin olmasını beklerim. & 4,53 & 0,90 \\
\hline & Konaklanacak otel personellerinin güler yüzlü olmasını beklerim. & 4,51 & 0,92 \\
\hline & Otellerin kahvaltı ve yemek salonlarının yeterli büyüklükte olmasını beklerim. & 4,51 & 0,97 \\
\hline & Turda yapılacak konaklamalar için seçilen otellerin kaliteli olmasını beklerim. & 4,48 & 0,97 \\
\hline & Konaklanacak otel odalarında klima sistemi olmasını beklerim. & 4,46 & 0,90 \\
\hline & Odalarda ücretsiz ikramların olmasını beklerim. & 4,42 & 1,01 \\
\hline & Konaklanacak otel odalarının yeterli büyüklükte olmasını beklerim. & 4,42 & 0,94 \\
\hline & Odalarda içecek hizmeti olmasını beklerim. & 4,36 & 1,00 \\
\hline & $\begin{array}{l}\text { İki veya daha fazla gün konaklanacak otellerde her gün oda temizliği yapılmasını } \\
\text { beklerim. }\end{array}$ & 4,31 & 0,95 \\
\hline & $\begin{array}{l}\text { Otel giriş çıkış işlemlerinin turu düzenleyen acenta tarafından yürütülmesini } \\
\text { beklerim. }\end{array}$ & 4,29 & 1,06 \\
\hline & Konaklanacak otellerin sosyal aktiviteler için kullanım alanı olmasını beklerim. & 4,27 & 1,05 \\
\hline & $\begin{array}{l}\text { Konaklanacak otel odalarında kıymetli eşyalar için, kıymetli eşya kasası olmasını } \\
\text { beklerim. }\end{array}$ & 4,17 & 1,06 \\
\hline
\end{tabular}

Konaklama/Yeme-İçme/Otel hizmetleri beklenti boyutunda yer alan ifadeler incelendiğinde, "Turda yapılacak konaklamalar için seçilen otellerin temiz olmasını beklerim" ifadesi $(X=4,68)$ bu boyutta yer alan en yüksek ortalamaya sahip ifade olmuştur. Bu boyutta yer alan en düşük ifade ise "Konaklanacak otel odalarında kıymetli eşyalar için, kıymetli eşya kasası olmasını beklerim" ifadesi $(X=4,17)$ olmuştur. Verilen cevaplardan, katılımcıların konaklamada önem verdikleri en önemli unsurun temizlik ve hijyen olduğu ifade edilebilir.

Rehberlik hizmetleri beklenti boyutunda yer alan "Rehberlerin tarih, sanat ve arkeoloji bilgisinin tatmin edici olmasını beklerim" ifadesi $(X=4,65)$ en yüksek ortalamaya sahip ifade 
Turist Rehberliği Dergisi (TURED) \& Yıl. 2020, Cilt. 3, Sayı. 1

Journal of Tour Guiding (JOTOG) \& Year. 2020, Volume. 3, Issue. 1

olmuştur. $\mathrm{Bu}$ boyut arasında yer alan, en düşük ifadeye sahip olan ise "Rehberlerin tur grubundaki herkesle ilgilenmesini beklerim ifadesidir" $(X=4,10)$.

Tablo 2: Katılımcıların Beklenti Düzeylerine İlişkin Görüşleri (Devamı)

\begin{tabular}{|c|c|c|c|}
\hline & & $\mathbf{X}$ & SS \\
\hline \multirow{17}{*}{ 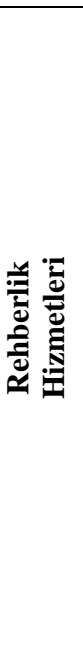 } & Rehberlerin tarih, sanat ve arkeoloji bilgisinin tatmin edici olmasını beklerim. & 4,65 & 0,86 \\
\hline & Rehberlerin dili etkin kullanmasını beklerim. & 4,61 & 0,87 \\
\hline & Rehberlerin tur programı ve içeriğini sıkıcı hale getirmemesini beklerim. & 4,59 & 0,87 \\
\hline & Rehberlerin gidilen yöre hakkında güncel bilgilere sahip olmasını beklerim. & 4,57 & 0,87 \\
\hline & Rehberlerin tarihi eser veya detaylara yer vermesini beklerim. & 4,55 & 0,90 \\
\hline & Rehberlerin tarihi yerleri ve geçmiş kültürleri iyi bilmesini beklerim. & 4,53 & 0,88 \\
\hline & Rehberlerin sorularıma tatmin edici cevaplar verebilmesini beklerim. & 4,51 & 0,88 \\
\hline & Rehberlerin ayrımcılık yapmadan herkese eşit yaklaşmasını beklerim. & 4,51 & 0,95 \\
\hline & Rehberlerin tarihler ve olaylar arasındaki bağlantıları iyi kurabilmesini beklerim. & 4,51 & 0,90 \\
\hline & Rehberlerin turun gerçekleşmesinde hevesli ve istekli olmasını beklerim. & 4,51 & 0,88 \\
\hline & Rehberlerin tur için belirlenen kurallara ve düzene uymasını beklerim. & 4,48 & 0,95 \\
\hline & Rehberlerin nazik, kibar, güler yüzlü ve samimi olmasını beklerim. & 4,46 & 0,92 \\
\hline & Rehberlerin grubu kontrol altına tutabilmesini beklerim. & 4,44 & 0,92 \\
\hline & Rehberlerin programa uyma konusunda titiz olmasını beklerim. & 4,44 & 0,95 \\
\hline & Rehberlerin sabırlı olmasını beklerim. & 4,40 & 0,97 \\
\hline & Rehberlerin her konuda yardımcı olmasını beklerim. & 4,21 & 0,99 \\
\hline & Rehberlerin tur grubundaki herkesle ilgilenmesini beklerim. & 4,10 & 1,00 \\
\hline
\end{tabular}

Uygulama gezisinden beklenti düzeylerinin boyutlarının demografik özelliklerine göre, çok fazla farklılaşma göstermediği görülmektedir, ( $>>0,05)$ (Tablo 3). Tablo 3 'de uygulama gezisi organizasyonundan ve hizmetlerinden beklenti düzeylerinin demografik özelliklere göre ciddi boyutlarda farklılık göstermediği görülmektedir. Uygulama gezisi organizasyonu ve hizmetlerinden beklenti boyutu cinsiyet değişkenine göre incelendiğinde, aralarında anlamlı bir farklılık saptanmamıştır $(\mathrm{p}>0,05)$. Tablo 3 'te verilen sonuçlara göre, kadınların uygulama gezisi organizasyon ve hizmetlerinden beklenti düzeylerinin erkeklere göre daha yüksek olduğu tespit edilmiştir. Uygulama gezisi organizasyonu ve hizmetlerinden beklenti boyutu medeni duruma göre ele alındığında, anlamlı bir farklılık saptanmamıştır $(\mathrm{p}>0,05)$. Evli olan katılımciların uygulama gezisi organizasyon ve hizmetlerinden beklenti düzeylerinin bekâr katılımcılara göre daha yüksek olduğu sonucu tespit edilmiştir. Uygulama gezisi organizasyonu ve hizmetlerinden beklenti boyutu yaş aralıklarına göre incelendiğinde ise, anlamlı bir farklılık saptanmamıştır $(\mathrm{p}>0,05)$. 35-54 yaş aralığında olan katılımcıların uygulama gezisi organizasyon ve hizmetlerinden beklenti düzeylerinin diğer yaş grubuna göre daha yüksek olduğu tespit edilmiştir.

Ulaşım hizmetlerinden beklenti düzeylerinin cinsiyete göre anlamlı bir farklılık göstermediği sonucuna ulaşılmışıı $(\mathrm{p}>0,05)$. Uygulama gezisine katılan kadınların erkeklere göre ulaşım beklentilerinin yüksek olduğu sonucu tespit edilmiştir. Ulaşım hizmetlerinden beklenti düzeyleri medeni duruma göre incelendiğinde, aralarında anlamlı bir farklılık saptanmamıştır $(p>0,05)$. Evli olan bireylerin ulaşım hizmetlerinden beklenti düzeylerinin daha yüksek olduğu tespit edilmiştir. Ulaşım hizmetlerinden beklenti düzeyleri yaş aralıklarına göre incelendiğinde ise aralarında anlamlı bir farklılık saptanmamıştır $(\mathrm{p}>0,05)$. Uygulama gezisine katılan 18-34 yaş aralığında olan genç bireylerin ulaşım hizmetlerinden beklenti düzeyleri diğer yaş aralığında olan bireylere göre daha yüksektir.

Konaklama/yeme-içme/otel hizmetlerinden beklenti düzeylerinin cinsiyete göre anlamlı bir farklılık göstermediği sonucuna ulaşılmıştır ( $\mathrm{p}>0,05)$. Uygulama gezisine katılan kadınların erkeklere göre konaklama/yeme-içme/otel beklentilerinin yüksek olduğu sonucu tespit edilmiştir. Konaklama/yeme-içme/otel hizmetlerinden beklenti düzeyleri medeni 
Turist Rehberliği Dergisi (TURED) \& Yıl. 2020, Cilt. 3, Sayı. 1

Journal of Tour Guiding (JOTOG) \& Year. 2020, Volume. 3, Issue. 1

duruma göre incelendiğinde, aralarında anlamlı bir farklılık saptanmamıştır ( $p>0,05)$. Evli olan bireylerin konaklama/yeme-içme/otel hizmetlerinden beklenti düzeylerinin daha yüksek olduğu tespit edilmiştir. Konaklama/yeme-içme/otel hizmetlerinden beklenti düzeyleri yaş aralıklarına göre incelendiğinde ise aralarında anlamlı bir farklılık saptanmamıştır ( $>0,05)$. Uygulama gezisinde katılan tüm yaş grubu bireylerin konaklama/yeme-içme/otel hizmetlerinden beklenti düzeyleri benzer olduğu, farklılık göstermedikleri anlaşılmıştır.

Rehberlik hizmetlerinden beklenti düzeylerinin demografik özelliklere göre incelendiğinde, cinsiyete göre anlamlı bir farklılık olmadığı tespit edilmiştir ( $p>0,05)$. Kadın katılımcıların rehberlik hizmetlerinden beklenti düzeylerinin daha yüksek olduğu sonucuna ulaşılmıştır. Rehberlik hizmetlerinden beklenti düzeyleri medeni duruma göre incelendiğinde, aralarında anlamlı bir farklılık saptanmamıştır $(p>0,05)$. Evli olan bireylerin rehberlik hizmetlerinden beklenti düzeylerinin daha yüksek olduğu tespit edilmiştir. Rehberlik hizmetlerinden beklenti düzeyleri yaş aralıklarına göre incelendiğinde ise aralarında anlamlı bir farklılık saptanmamıştır ( $\mathrm{p}>0,05)$. Uygulama gezisinde katılan 35-54 yaş aralığında olan bireylerin rehberlik hizmetlerinden beklenti düzeyleri diğer yaş aralığında olan bireylere göre daha yüksek olduğu sonucuna ulaşılmıştır.

Tablo 3.Uygulama Gezisinden Beklenti Boyutlarının Demografik Özelliklere Göre Farklılaşma Durumu

\begin{tabular}{|c|c|c|c|c|c|c|c|}
\hline \multirow{7}{*}{$\begin{array}{l}\text { Uygulama Gezisi } \\
\text { Organizasyonu ve } \\
\text { Hizmetleri }\end{array}$} & & & $\mathbf{N}$ & $\mathbf{X}$ & SS & $\mathbf{T}$ & $\mathbf{P}$ \\
\hline & \multirow{2}{*}{ Cinsiyet } & Kadın & 10 & 4,82 & 0,22 & \multirow{2}{*}{1,316} & \multirow{2}{*}{, 195} \\
\hline & & Erkek & 37 & 4,43 & 0,91 & & \\
\hline & \multirow{2}{*}{ Medeni Durum } & Bekâr & 30 & 4,44 & 0,98 & \multirow{2}{*}{,- 800} & \multirow{2}{*}{,428 } \\
\hline & & Evli & 17 & 4,64 & 0,44 & & \\
\hline & \multirow{2}{*}{ Yaş } & $18-34$ & 35 & 4,49 & 0,95 & \multirow{2}{*}{,094 } & \multirow{2}{*}{,963 } \\
\hline & & $35-54$ & 12 & 4,59 & 0,50 & & \\
\hline \multirow{6}{*}{ Ulaşım Hizmetleri } & \multirow{2}{*}{ Cinsiyet } & Kadın & 10 & 4,70 & 0,23 & \multirow{2}{*}{1,272} & \multirow{2}{*}{,210 } \\
\hline & & Erkek & 37 & 4,30 & 0,96 & & \\
\hline & \multirow{2}{*}{ Medeni Durum } & Bekâr & 30 & 4,37 & 0,98 & \multirow{2}{*}{,- 134} & \multirow{2}{*}{,894 } \\
\hline & & Evli & 17 & 4,41 & 0,68 & & \\
\hline & \multirow{2}{*}{ Yaş } & $18-34$ & 35 & 4,40 & 0,93 & \multirow{2}{*}{,637 } & \multirow{2}{*}{,596 } \\
\hline & & $35-54$ & 12 & 4,30 & 0,75 & & \\
\hline \multirow{6}{*}{$\begin{array}{l}\text { Konaklama, Yeme- } \\
\text { İçme, Otel Hizmetleri }\end{array}$} & \multirow{2}{*}{ Cinsiyet } & Kadın & 10 & 4,75 & 0,30 & \multirow{2}{*}{1,263} & \multirow{2}{*}{,213 } \\
\hline & & Erkek & 37 & 4,37 & 0,92 & & \\
\hline & \multirow{2}{*}{ Medeni Durum } & Bekâr & 30 & 4,42 & 0,98 & \multirow{2}{*}{,- 305} & \multirow{2}{*}{,762 } \\
\hline & & Evli & 17 & 4,50 & 0,53 & & \\
\hline & \multirow{2}{*}{ Yaş } & $18-34$ & 35 & 4,45 & 0,94 & \multirow{2}{*}{, 111} & \multirow{2}{*}{,953 } \\
\hline & & $35-54$ & 12 & 4,45 & 0,61 & & \\
\hline \multirow{6}{*}{ Rehberlik Hizmetleri } & \multirow{2}{*}{ Cinsiyet } & Kadın & 10 & 4,73 & 0,34 & \multirow{2}{*}{1,108} & 274 \\
\hline & & Erkek & 37 & 4,41 & 0,90 & & , 2/4 \\
\hline & Medeni Durum & Bekâr & 30 & 4,43 & 0,99 & 461 & 647 \\
\hline & Medenı Durum & Evli & 17 & 4,55 & 0,41 &,- 461 & 647 \\
\hline & & $18-34$ & 35 & 4,42 & 0,94 & 138 & \\
\hline & Yaş & $35-54$ & 12 & 4,67 & 0,43 & ,438 &, 727 \\
\hline
\end{tabular}

Tablo 4'te katılımcıların memnuniyet düzeylerine ilişkin görüşlerine yer verilmiştir. Katılımcıların uygulama gezisi organizasyonu ve hizmetlerinden memnuniyet boyutunda yer alan ifadelerde "Tura başlamadan önce uygulanması gereken kurallar hakkında bilgilendirildik" ifadesi $(X=3,87)$ en yüksek ortalamaya sahiptir. Bu boyutta en düşük ortalamaya sahip olan ifade ise "Acentanın zimmetimize verdiği headset ve kulakllklar düzgün çalışıyordu" ifadesi $(\mathrm{X}=2,61)$ olmuştur. Bu cevaplardan, katılımcıların tur öncesi kurallar hakkında bilgilendirildikleri ve uygulama gezisi esnasında verilen headset ve kulaklıkların düzgün çalışmadığı çıkarılabilir. Ulaşım hizmetlerinden memnuniyet boyutunda yer alan 
Turist Rehberliği Dergisi (TURED) \& Yıl. 2020, Cilt. 3, Sayı. 1

Journal of Tour Guiding (JOTOG) \& Year. 2020, Volume. 3, Issue. 1

ifadeler incelendiğinde, en yüksek ortalamaya sahip olan ifade "Otobüs şoförleri sabırlıydı" ifadesi $(X=4,27)$ olurken; en düşük ortalamaya sahip olan ifade ise "Araçta telefon, tablet vb. aletleri şarj edebilmek için araç prizleri çalışıyordu" ifadesi $(X=2,95)$ olmuştur. Konaklama/Yeme-İçe/Otel hizmetleri memnuniyet boyutunda yer alan ifadeler incelendiğinde, en yüksek ortalamaya sahip olan ifade "Konaklanan otel odalarında klima sistemi çalışıyordu ifadesi $(\mathrm{X}=3,82)$ olmuştur. İfadeler arasında yer alan en düşük ortalamaya sahip olan ifade ise "Otel giriş çıkış işlemleri turu düzenleyen acente tarafından yürütüldü" ifadesi $(\mathrm{X}=3,17)$ olmuştur. $\mathrm{Bu}$ cevaplardan, otel giriş çıkış işlemlerinin turu düzenleyen acente tarafından yapılmadığı sonucu çıkarılabilir. Rehberlik hizmeti memnuniyet boyutunda yer alan ifadelere bakıldığında, en yüksek ortalamaya sahip olan ifadenin "Rehberler nazik, kibar, güler yüzlü ve samimiydiler" ifadesi $(X=4,17)$ olduğu tespit edilmiştir. En düşük ortalamaya sahip olan ifadenin ise "Rehberler gidilen yöre hakkında güncel bilgilere sahipti" ifadesi (X $=3,65)$ olmuştur. $\mathrm{Bu}$ boyutta verilen cevaplardan katılımcıların rehberlerin gidilen destinasyonlar hakkında güncel bilgilere sahip olmadığını düşündüğü anlaşılabilir.

Tablo 4: Katılımcıların Memnuniyet Düzeylerine İlişkin Görüşleri

\begin{tabular}{|c|c|c|c|}
\hline & & $\mathbf{X}$ & SS \\
\hline \multirow{9}{*}{ 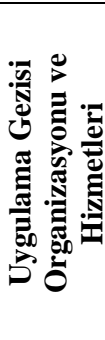 } & Tura başlamadan önce uygulanması gereken kurallar hakkında bilgilendirildik. & 3,87 & 1,27 \\
\hline & Turun yeni şeyler öğrenmemizi sağladı. & 3,61 & 1,29 \\
\hline & Uygulama gezisi başvuru işlemleri kolaydı. & 3,48 & 1,19 \\
\hline & Tura başlamadan önce ziyaret edeceğimiz yerler hakkında bilgilendirildik. & 3,14 & 1,54 \\
\hline & Tura başlamadan önce genel olarak turla ilgili bilgilendirildik. & 3,04 & 1,62 \\
\hline & Uygulama gezisi ücret ödemesinde taksit imkânı vardı. & 3,02 & 1,51 \\
\hline & Tur programı iyi organize edilmişti. & 2,87 & 1,49 \\
\hline & Uygulama gezisi ücretinin pahalı değildi. & 2,82 & 1,46 \\
\hline & Acentanın zimmetimize verdiği headset ve kulaklıklar düzgün çalıșıordu. & 2,61 & 1,45 \\
\hline \multirow{11}{*}{ 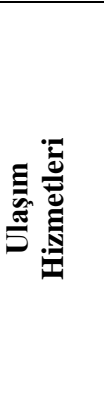 } & Otobüs şoförleri sabırlıydı. & 4,27 & 1,03 \\
\hline & Aracın içi ve dışı temizdi. & 4,04 & 1,02 \\
\hline & Aracın kliması çalışıyordu. & 3,97 & 1,09 \\
\hline & Otobüs şoförleri güler yüzlüydü. & 3,95 & 1,14 \\
\hline & Otobüs şoförleri yolları iyi biliyorlardı. & 3,95 & 1,06 \\
\hline & Araçta iki tane şoför vardı. & 3,87 & 1,40 \\
\hline & Araçta içecek servisi yapıldı. & 3,51 & 1,34 \\
\hline & Araçta bir tane muavin vardı. & 3,42 & 1,52 \\
\hline & Tur için kullanılacak aracın beş yaşından büyük değildi. & 3,38 & 1,37 \\
\hline & Tur boyunca yapılan yolculuklar konforluydu. & 3,25 & 1,29 \\
\hline & Araçta telefon, tablet vb. aletleri şarj edebilmek için araç prizleri çalışıyordu. & 2,95 & 1,60 \\
\hline \multirow{16}{*}{ 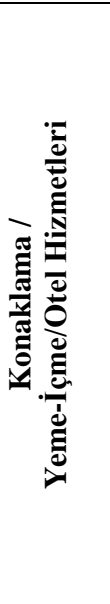 } & Konaklanan otel odalarında klima sistemi çalışıyordu. & 3,82 & 0,93 \\
\hline & İki veya daha fazla gün konaklanan otellerde her gün oda temizliği yapıldı. & 3,80 & 1,09 \\
\hline & Konaklanan otel personelleri güler yüzlüydü. & 3,80 & 1,03 \\
\hline & Otellerin kahvaltı ve yemek salonları yeterli büyüklükteydi. & 3,76 & 0,98 \\
\hline & Odalarda internet kullanımı ücretsizdi. & 3,76 & 1,14 \\
\hline & Konaklanan otel odalarında kıymetli eşyalar için, kıymetli eşya kasası vardı. & 3,70 & 1,08 \\
\hline & Konaklanan otel odalarındaki banyolar ve tuvaletler hijyenikti. & 3,65 & 1,06 \\
\hline & Otellerde verilen yemekler ve yemek hizmetleri iyiydi. & 3,61 & 1,11 \\
\hline & Konaklanan otel odaları yeterli büyüklükteydi. & 3,61 & 1,03 \\
\hline & Odalarda içecek hizmeti veriliyordu. & 3,57 & 1,13 \\
\hline & Konaklanan otellerin sosyal aktiviteler için kullanım alanları vardı. & 3,55 & 1,11 \\
\hline & Turda yapılan konaklamalar için seçilen oteller temizdi. & 3,46 & 1,15 \\
\hline & Odalarda ücretsiz ikramlar vardı. & 3,40 & 1,20 \\
\hline & Konaklanan otellerde çamaşır yıkama ve ütüleme hizmeti vardı. & 3,31 & 1,38 \\
\hline & Turda yapılan konaklamalar için seçilen oteller kaliteliydi. & 3,31 & 1,21 \\
\hline & Otel giriş çıkış işlemleri turu düzenleyen acenta tarafından yürütüldü. & 3,17 & 1,49 \\
\hline
\end{tabular}


Turist Rehberliği Dergisi (TURED) \& Yıl. 2020, Cilt. 3, Sayı. 1

Journal of Tour Guiding (JOTOG) \& Year. 2020, Volume. 3, Issue. 1

Tablo 4: Katılımcıların Memnuniyet Düzeylerine İlişkin Görüşleri (Devamı)

\begin{tabular}{|l|l|c|c|}
\hline & & X & SS \\
\hline \multirow{4}{*}{} & Rehberler nazik, kibar, güler yüzlü ve samimiydiler. & 4,17 & 1,00 \\
\cline { 2 - 4 } & Rehberler yeterince sabırlı davrandılar. & 4,14 & 1,08 \\
\cline { 2 - 4 } & Rehberler dili etkin kullanıyordu. & 4,08 & 1,15 \\
\cline { 2 - 4 } & Rehberler her konuda yardımcı oldular. & 3,95 & 1,14 \\
\cline { 2 - 4 } & Rehberler tarihler ve olaylar arasındaki bağlantıları iyi kurabildiler. & 3,91 & 1,11 \\
\cline { 2 - 4 } & Rehberlerin tarih, sanat ve arkeoloji bilgisi tatmin ediciydi. & 3,91 & 1,21 \\
\cline { 2 - 4 } & Rehberler tur grubundaki herkesle ilgilendi. & 3,85 & 1,16 \\
\cline { 2 - 4 } & Rehberler ayrımcılık yapmadan herkese eşit yaklaşım sergilediler. & 3,82 & 1,38 \\
\cline { 2 - 4 } & Rehberler grubu kontrol altında tutabildiler. & 3,82 & 1,20 \\
\cline { 2 - 4 } & Rehberler tarihi yerleri ve geçmiş kültürleri iyi biliyorlardı. & 3,82 & 1,12 \\
\cline { 2 - 4 } & Rehberler turun gerçekleşmesinde hevesli ve istekliydi. & 3,82 & 1,23 \\
\cline { 2 - 4 } & Rehberler tur için belirlenen kurallara ve düzene uydular. & 3,78 & 1,23 \\
\cline { 2 - 4 } & Rehberler tarihi eser veya detaylara yer verdi. & 3,76 & 1,21 \\
\cline { 2 - 4 } & Rehberler tur programı içeriğini eğlenceli hale getirdi. & 3,72 & 1,24 \\
\cline { 2 - 4 } & Rehberler programa uyma konusunda titiz davrandır. & 3,72 & 1,24 \\
\cline { 2 - 4 } & Rehberler sorularıma tatmin edici cevaplar verebildiler. & 3,68 & 1,23 \\
\cline { 2 - 4 } & Rehberler gidilen yöre hakkinda güncel bilgilere sahipti. & 3,65 & 1,18 \\
\hline
\end{tabular}

Tablo 5'te uygulama gezisinden memnuniyet boyutunun demografik özelliklere göre farklılaşma durumu verilmiştir. Katılımcı görüşlerinin bireysel özelliklere (cinsiyet, yaş, medeni durum) göre karşılaştırılmasında (iki grup için) bağımsız örneklemler için uygulanan $\mathrm{t}$ testi (Independent Samples $\mathrm{t}$ test) sonuçlarına göre uygulama gezisinden memnuniyet boyutlarından uygulama gezisi organizasyon ve hizmetlerinden memnuniyet düzeylerinin cinsiyete göre anlamlı bir farklılık gösterdiği saptanmıştır $(p<0,05)$. Uygulama gezisine katılan erkeklerin uygulama gezisi organizasyon ve hizmetlerinden memnuniyet düzeylerinin kadınlara göre daha yüksek olduğu sonucuna ulaşılmıştır. Uygulama gezisi organizasyon ve hizmetlerinden memnuniyet düzeyleri medeni duruma göre incelendiğinde anlamlı bir farklılık saptanmıştır. Evli olan katılımcıların uygulama gezisi organizasyon ve hizmetlerinden memnuniyet düzeylerinin bekâr katılımcılara göre daha yüksek olduğu sonucu tespit edilmiştir $(\mathrm{p}<0,05)$. Uygulama gezisi organizasyon ve hizmetlerinden memnuniyet düzeyleri yaş aralıklarına göre incelendiğinde ise anlamlı bir farklılık saptanmamıştır ( $p>0,05)$. 35-54 yaş aralığında olan katılımcıların uygulama gezisi organizasyon ve hizmetlerinden memnuniyet düzeylerinin daha yüksek olduğu belirlenmiştir.

Ulaşım hizmetlerinden memnuniyet düzeyleri incelendiğinde, cinsiyete göre anlamlı bir farklılık olmadığı saptanmıştır $(\mathrm{p}>0,05)$. Erkek katılımcıların kadınlara göre ulaşım hizmetlerinden memnuniyet düzeylerinin daha yüksek olduğu tespit edilmiştir. Ulaşım hizmetlerinden memnuniyet düzeyleri medeni duruma göre değerlendirildiğinde anlamlı bir farklı1ık saptanmamıştır $(\mathrm{p}>0,05)$. Bekâr olan katılımcıların ulaşım hizmetlerinden memnuniyet düzeylerinin daha yüksek olduğu sonucu ortaya çıkmıştır. Ulaşım hizmetlerinden memnuniyet düzeyleri yaş aralıklarına göre incelendiğinde ise anlamlı bir farklılık bulunamamıştır $(\mathrm{p}>0,05)$. 35-54 yaş aralığında olan bireylerin ulaşım hizmetlerinden memnuniyet düzeylerinin daha yüksek olduğu sonucuna ulaşılmıştır.

Konaklama/yeme-içme/otel hizmetlerinden memnuniyet düzeyleri incelendiğinde, cinsiyete göre anlamlı bir farklılık gösterdiği saptanmıştır $(\mathrm{p}<0,05)$. Erkek katılımcıların kadınlara göre konaklama/yeme-içme/otel hizmetlerinden memnuniyet düzeylerinin daha yüksek olduğu tespit edilmiştir. Konaklama/yeme-içme/otel hizmetlerinden memnuniyet düzeyleri medeni duruma göre değerlendirildiğinde anlamlı bir farklılık saptanmamıştır $(\mathrm{p}>0,05)$. Evli olan katılımcıların konaklama/yeme-içme/otel hizmetlerinden memnuniyet düzeylerinin daha yüksek olduğu sonucu ortaya çıkmıştır. Konaklama/yeme-içme/otel 
Turist Rehberliği Dergisi (TURED) \& Yıl. 2020, Cilt. 3, Sayı. 1

Journal of Tour Guiding (JOTOG) \& Year. 2020, Volume. 3, Issue. 1

hizmetlerinden memnuniyet düzeyleri yaş aralıklarına göre incelendiğinde ise anlamlı bir farklılık bulunamamıştır $(\mathrm{p}>0,05)$. 35-54 yaş aralığında olan bireylerin konaklama/yemeiçme/otel hizmetlerinden memnuniyet düzeylerinin daha yüksek olduğu sonucuna ulaşılmıştır.

Rehberlik hizmetlerinden memnuniyet düzeyi cinsiyete göre ele alındığında anlamlı bir farklılık gösterdiği saptanmıştır $(\mathrm{p}<0,05)$. Erkek katılımcıların rehberlik hizmetlerinden memnuniyet düzeylerinin kadın katılımcılara göre daha yüksek olduğu belirlenmiştir. Rehberlik hizmetlerinden memnuniyet düzeyi medeni duruma göre değerlendirildiğinde ise aralarında anlamlı bir farklılık saptanmamıştır $(p>0,05)$. Uygulama gezisine katılan evlilerin rehberlik hizmetlerinden memnuniyet düzeyinin bekâr katılımcılara göre daha yüksek olduğu tespit edilmiştir. Rehberlik hizmetleri yaş aralıklarına göre incelendiğinde ise anlamlı bir farklılık saptanmamıştır ( $>0,05)$. Uygulama gezisine katılan 35-54 yaş aralı̆̆ında olan bireylerin, diğer yaş aralıklarında olan bireylere göre rehberlik hizmetlerinden memnuniyet düzeyleri daha yüksektir.

Tablo 5: Uygulama Gezisinden Memnuniyet Boyutunun Demografik Özelliklere Göre Farklılaşma Durumu

\begin{tabular}{|c|c|c|c|c|c|c|c|}
\hline \multirow{7}{*}{ 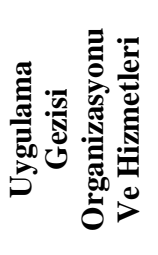 } & & & $\mathbf{N}$ & $\mathbf{X}$ & Ss & $\mathbf{t}$ & $\mathbf{p}$ \\
\hline & \multirow{2}{*}{ Cinsiyet } & Kadın & 10 & 2,46 & 0,50 & \multirow{2}{*}{$-3,512$} & \multirow{2}{*}{,001 } \\
\hline & & Erkek & 37 & 3,35 & 1,19 & & \\
\hline & \multirow{2}{*}{ Medeni Durum } & Bekâr & 30 & 2,90 & 1,06 & \multirow{2}{*}{$-2,226$} & \multirow{2}{*}{,031 } \\
\hline & & Evli & 17 & 3,64 & 1,14 & & \\
\hline & \multirow{2}{*}{ Yaş } & $18-34$ & 35 & 2,95 & 1,12 & \multirow{2}{*}{1,670} & \multirow{2}{*}{, 188} \\
\hline & & $35-54$ & 12 & 3,79 & 1,09 & & \\
\hline \multirow{6}{*}{ 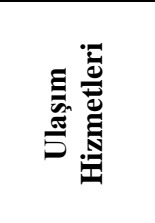 } & \multirow{2}{*}{ Cinsiyet } & Kadın & 10 & 3,49 & 0,98 & \multirow{2}{*}{,- 713} & \multirow{2}{*}{, 480 } \\
\hline & & Erkek & 37 & 3,74 & 1,01 & & \\
\hline & \multirow{2}{*}{ Medeni Durum } & Bekâr & 30 & 3,71 & 0,96 & \multirow{2}{*}{, 177} & \multirow{2}{*}{, 861} \\
\hline & & Evli & 17 & 3,65 & 1,10 & & \\
\hline & \multirow{2}{*}{ Yaş } & $18-34$ & 35 & 3,66 & 0,98 & \multirow{2}{*}{,265 } & \multirow{2}{*}{, 850} \\
\hline & & $35-54$ & 12 & 3,80 & 1,17 & & \\
\hline \multirow{6}{*}{ 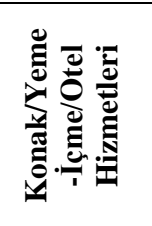 } & \multirow{2}{*}{ Cinsiyet } & Kadın & 10 & 3,03 & 0,62 & \multirow{2}{*}{$-2,104$} & \multirow{2}{*}{,041 } \\
\hline & & Erkek & 37 & 3,73 & 1,00 & & \\
\hline & \multirow{2}{*}{ Medeni Durum } & Bekâr & 30 & 3,43 & 0,97 & \multirow{2}{*}{$-1,468$} & \multirow{2}{*}{, 149} \\
\hline & & Evli & 17 & 3,86 & 0,94 & & \\
\hline & \multirow{2}{*}{ Yaş } & $18-34$ & 35 & 3,40 & 0,96 & \multirow{2}{*}{2,021} & \multirow{2}{*}{, 125} \\
\hline & & $35-54$ & 12 & 4,10 & 0,87 & & \\
\hline \multirow{6}{*}{ 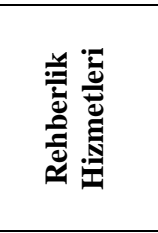 } & \multirow{2}{*}{ Cinsiyet } & Kadın & 10 & 3,27 & 0,64 & \multirow{2}{*}{$-2,049$} & \\
\hline & & Erkek & 37 & 4,02 & 1,09 & & ,046 \\
\hline & & Bekâr & 30 & 3,68 & 1,10 & & \\
\hline & Medeni Durum & Evli & 17 & 4,18 & 0,91 & $-1,596$ &, 117 \\
\hline & & $18-34$ & 35 & 3,64 & 1,09 & & 080 \\
\hline & Yaş & $35-54$ & 12 & 4,55 & 0,52 & 2,413 & ,080 \\
\hline
\end{tabular}

Aşağıda katılımcıların uygulama gezilerinden beklenti ve memnuniyet düzeylerinin boyutlarına göre karşılaştırıldığı Tablo 6 yer almaktadır. Tüm boyutlarda beklenti düzeylerinin memnuniyet düzeylerine göre çok daha yüksek olduğu tespit edilmiştir. Diğer bir ifadeyle katılımcıların tüm hizmet boyutlarında uygulama gezilerinden bekledikleri düzeyde hizmet alamadıkları tespit edilmiştir. Uygulama gezisi organizasyon ve hizmetlerinden beklenti ve memnuniyet düzeyleri karşılaştıııldığında, ikisi arasında anlamlı bir farklılık saptandığı tespit edilmiştir $(\mathrm{p}<0,05)$. Uygulama gezisi organizasyon ve hizmetlerinden beklenti düzeylerinin, memnuniyet düzeylerinden daha yüksek olduğu sonucuna ulaşılmıştır. Ulaşım hizmetlerinden beklenti ve memnuniyet düzeyleri arasında anlamlı bir farklılık saptanmıştır $(\mathrm{p}<0,05)$. Ulaşım hizmetlerinden memnuniyet düzeyinin, beklenti düzeyinden düşük olduğu tespit edilmiştir. Konaklama/yeme-içme/otel hizmetlerinden beklenti ve memnuniyet düzeyleri arasında 
Turist Rehberliği Dergisi (TURED) \& Yıl. 2020, Cilt. 3, Sayı. 1

Journal of Tour Guiding (JOTOG) \& Year. 2020, Volume. 3, Issue. 1

yapılan analiz sonucu anlamlı bir farklılık saptanmıştır $(\mathrm{p}<0,05)$. Konaklama/yeme-içme/otel hizmetlerinden memnuniyet düzeylerinin beklenti düzeylerinden düşük olduğu görülmüştür. Katılımcıların rehberlik hizmetlerinden beklenti ve memnuniyet düzeyleri karşılaştırıldığında ise rehberlik hizmetleri beklenti ve memnuniyet düzeyleri arasında anlamlı bir farklılık görülmüştür $(p<0,05)$. Katılımciların rehberlik hizmetlerinden memnuniyet düzeylerinin beklenti düzeylerine göre düşük olduğu görülmüştür.

Tablo 6: Katılımcıların Beklenti ve Memnuniyet Düzeylerinin Karşılaştııılması

\begin{tabular}{|c|c|c|c|c|c|}
\hline & $\mathrm{N}$ & $\mathrm{X}$ & ss & $\mathbf{t}$ & $\mathbf{p}$ \\
\hline Uygulama gezisi organizasyonu ve hizmetlerinden beklenti & 47 & 4,51 & 0,83 & \multirow{2}{*}{7,325} & \multirow{2}{*}{,000 } \\
\hline Uygulama gezisi organizasyonu ve hizmetlerinden memnuniyet & 47 & 3,16 & 1,14 & & \\
\hline Ulaşım hizmetlerinden beklenti & 47 & 4,38 & 0,87 & \multirow{2}{*}{4,774} & \multirow{2}{*}{,000 } \\
\hline Ulaşım hizmetlerinden memnuniyet & 47 & 3,69 & 1,00 & & \\
\hline Konaklama/yeme-içme/otel hizmetlerinden beklenti & 47 & 4,45 & 0,84 & \multirow{2}{*}{6,102} & \multirow{2}{*}{, 000 } \\
\hline Konaklama/yeme-içme/otel hizmetlerinden memnuniyet & 47 & 3,58 & 0,97 & & \\
\hline Rehberlik hizmetlerinden beklenti & 47 & 4,47 & 0,82 & \multirow{2}{*}{4,458} & \multirow{2}{*}{, 000} \\
\hline Rehberlik hizmetlerinden memnuniyet & 47 & 3,86 & 1,05 & & \\
\hline
\end{tabular}

\section{Sonuç ve Öneriler}

Turizm, ülke ekonomilerine önemli ölçüde döviz girdisi sağlayan önemli bir piyasadır. Türkiye'nin turizm coğrafyası çok geniş olduğundan büyük bir araştırma hacmine sahiptir. Turizm olayını temel düzeyde bile anlayabilmek için sosyoloji bilgisine gereksinim vardır. Sosyoloji bilmeyen bir turizmcinin başarı şansı oldukça düşüktür. Zira toplumu, toplumları bilmeyen ve incelemeyen bir turizm işletmecisinin, ne insan kaynaklarında ne de turizm pazarlamasında başarılı olması beklenemez. Turizm sayesinde yabancılaşmanın etkileri azalarak insanların sosyalleşmesine katkıda bulunarak psikolojik iyilik durumlarını olumlu yönde etkilemektedir. Turizm bir ülke açısından en önemli sektörlerden biridir. Özellikle Türkiye gibi doğal ve kültürel zenginlikleri bulunan ülkeler açısından turizm ekonomik, politik başta olmak üzere pek çok açıdan büyük öneme sahiptir. Turizm, 30'dan fazla alt iş kolu üzerinde doğrudan etkisi olan ve gelir kapısı olan bir sektör olduğundan ülkeye büyük ekonomik kazanımlar sağlamaktadır.

Turist rehberlerinin turizm alanındaki rolleri göz ardı edilemez. Uluslararası Tur Yöneticileri Birliği bir turist rehberinin görevini tur katılımcılarına veya bireysel turistlere bulunulan coğrafyadaki destinasyonlarla ilgili bilgileri ziyaretçilerin talep ettikleri lisan ile kültür, doğal miras ve çevre bağlamında eğlenceli ve yorumlu bir şekilde aktarmak şeklinde açıklamıştır. Turist rehberi, gezilen destinasyonun algısı açısından büyük bir etkiye sahiptir. Turist rehberinin, turiste gezilen bölgeye ilişkin sahip olduğu önyargıları yıkma ve algılarını değiştirme gibi bir etkisi olmaktadır. Turist rehberinin destinasyon için pozitif bir etki oluşturması sonucunda turistin bu destinasyonu tavsiye etme olasıllğ 1 artacağ gibi bu bölgeyi tekrar ziyaret etmeye de eğilimi olacaktır.

Kültür ve Turizm Bakanlığı'nın acil olarak gereksinim duyduğu turist rehberi gereksinimi karşıladıktan sonra daha kaliteli turist rehberleri yetiştirmek adına örgün öğretimde eğitimi yürürlüğe koymuştur. Öğrenciler, mezun olmadan önce uygulama gezisine katılma hakkı kazanmaktadır. Eğitimini yaygın veya örgün eğitim olarak görüp görmediği fark etmeksizin çalışma kartı almak isteyen tüm rehber adaylarının dil yeterliliği ve uygulama gezi şartlarını yerine getirmelidir.

Uygulama gezileri, öğrencilerin turist rehberi olmadan önce yerine getirdikleri ilk aşama ve ilk tecrübe olması bakımından bir hayli önemli bulunmakta ve katılımcılar turist rehberliğinin nasıl tatbik edildiğini aktif bir şekilde öğrenmektedirler. Bu gezilere olan ilgi

Manav ve Soybalı; Turist Rehberi Adaylarının Uygulama Gezilerinden Beklentilerinin ve Memnuniyet

Düzeylerinin Araştırılması / Investigation of Tourist Guide Candidates' Expectations and Satisfaction Levels from the Training Tours 


\section{IIIIII}

Turist Rehberliği Dergisi (TURED) \& Yıl. 2020, Cilt. 3, Sayı. 1

Journal of Tour Guiding (JOTOG) \& Year. 2020, Volume. 3, Issue. 1

öğrenciden öğrenciye farklılık göstermektedir. Bunun asıl sebebi, öğrencinin gerçekten turist rehberi olmay1 isteyip istememesi olsa da gezinin maliyeti de katılım konusu üzerinde etkili olan önemli faktörlerdendir. Gezi süresinin uzun olması, gezinin ilk haftasından sonra yorgunluk ve motivasyon düşüklügüne yol açtığı için aktif ve bilinçli bir katılım sergilenememektedir. Bu durum da istenen verimin alınamamasına yol açmaktadır. Uygulama gezilerinin gerek maddi açıdan gerekse motivasyon düşüklüğü sebebiyle yaşanan performans kaybının engellenmesi açısından bir yıla yayılarak gerçekleştirilmesi, eğitimin nitelikli eğitmenler tarafından verilmesi ve eğitimin kalitesinin iyileştirilmesi tavsiye edilmektedir. Uygulama gezileri, turizm sektörü içerisinde yer alan turist rehberleri için önemli ve gerekli bir uygulamadır. Bunun nedeni ise öğrenciler, rehberlik yapmaya başlamadan önce katıldıkları uygulama gezilerinde gelecekte bu mesleği yapıp yapamayacaklarını, rehberlik mesleğini nasıl yapmalarını gerektiği gibi konuları anlayacaklardır. Bu açıdan, uygulama gezileri turist rehberleri açısından önem taşımaktadır (Ön Esen ve Gülmez, 2018: 334). Katılımcıların memnuniyet düzeylerin, beklenti düzeylerinden düşük olması rehber adaylarının uygulama gezilerinden bekledikleri düzeyde hizmet alamamaları, mesleğe bakış açılarını ve 1sınma hızlarını olumsuz etkileyecektir. Bu yüzden araştırma uygulama gezilerini düzenleyenlerin bu konuda daha dikkatli olmalarına ve memnuniyet düzeyini yükseltmek amacıyla daha fazla çalışmaları gerektiğine işaret etmektedir.

\section{Kaynakça}

Arslantürk, Y. (2016). Mesleki Bağll1ık: Turist Rehberleri Üzerine Bir İnceleme, İşletme Araştırmaları Dergisi, 8 (1), 186-207.

Çolakoğlu O., Epik F. ve Efendi, E. (2014). Tur Yönetimi ve Turist Rehberliği (2. Baskı), Ankara: Detay Yayınc1lik.

Erdem, B. ve Etiz, N. (2012). Turist Rehberliği Bölümü Öğrencilerinin Rehberlik Tatbikat Gezisi Algıları: Balıkesir Üniversitesi TİOYO Örneği, içinde Turizm Eğitimi Konferansı Tebliğler, 323-335, Ankara, Türkiye, 2012.

Güzel, Ö. (2007). Türkiye İmajını Geliştirilmesinde Profesyonel Turist Rehberlerinin Rolü Alman Turistler Üzerine Bir Araştırma, (Yayınlanmamış Yüksek Lisans Tezi). Balıkesir: Balıkesir Üniversitesi Sosyal Bilimler Enstitüsü.

Güzel, Ö., Türker, A. ve Şahin, İ. (2014). Profesyonel Turist Rehberlerinin Algıladıkları Mesleki Engelleri Belirlemeye Yönelik Bir Araştırma, Gazi Üniversitesi Turizm Fakültesi Dergisi, 2, 173-190.

Kozak, N., Meryem A. K. ve Kozak, M. (2008). Genel Turizm: Illkeler Kavramlar (7. Baskı), Ankara: Detay Yayınc1lik.

Ön Esen, F. ve Gülmez, M. (2018). Turist Rehberliği Yurtiçi Uygulama Gezilerinin Öğrenciler Açısından Önemi: Akademisyenler ve Turist Rehberleri Üzerine Bir Araştırma, Seyahat ve Otel İsletmeciliği Dergisi, 15 (2), 320-335.

Turist Rehberliği Meslek Yönetmeliği. (2014). Resmi Gazete (28568). Erişim adresi: https://www.mevzuat.gov.tr/mevzuat?MevzuatNo=17151\&MevzuatTur=7\&MevzuatTert $\mathrm{ip}=5$ 
Turist Rehberliği Dergisi (TURED) \& Yıl. 2020, Cilt. 3, Sayı. 1

Journal of Tour Guiding (JOTOG) \& Year. 2020, Volume. 3, Issue. 1

\section{ETIKK ve BILLIMSEL ILKELER SORUMLULUK BEYANI}

Bu çalışmanın tüm hazırlanma süreçlerinde (veri toplama, yazım vb.), tüm etik kurallara ve bilimsel atıf gösterme ilkelerine riayet edildiğini, herhangi bir hataya mahal vermemek için yayımdan önce makalenin bir intihal programı aracılığıyla da kontrol edildiğini yazarlar beyan eder. Ayrıca yazarlar aşağıda sıralanan hususları kabul etmiştir:

1. Çalışmada yer alan ve kullanılan tüm kaynaklara, bilimsel araştırma yöntemleri ve etik ilkeler doğrultusunda atıf yapılmıştır.

2. Çalışmada tüm yazarların akademik-bilimsel olarak doğrudan ve ortak katkısı vardır.

3. Bu çalıșma, yazarların özgün bir çalıșmasıdır.

4. Bütün yazarlar dergiye gönderilen makaleyi görmüş ve sonuçlarını onaylamıştır.

5. Çalışmada kullanılan denek/deneklere ilişsin herhangi bir etik ihlal yapılmamış, kullanılan tüm veri toplama yöntemlerinde bilimsel etik ilkelere göre hareket edilmiştir.

6. Çalışma daha önceden bilimsel bir toplantıda sunulan özet veya bu çalışmanın daha kısa hali ise, makalede bu durum belirtilmiştir.

7. Çalışmada, hiçbir suç unsuru veya kanuna aykırı ifade bulunmamakla birlikte, araştırma yapılırken kanuna aykırı herhangi bir yöntem kullanılmamış olup, çalışma ile ilgili tüm yasal izinler alınmış ve etik kurallara uygun hareket edilmiştir.

Aksi bir durumun tespiti halinde Turist Rehberliği Dergisi’nin hiçbir sorumluluğu olmayıp, tüm sorumluluk makale yazarlarına aittir.

Tarih : $21 / 06 / 2020$

Sorumlu Yazar : Doç. Dr. Hasan Hüseyin SOYBALI

Manav ve Soybali; Turist Rehberi Adaylarının Uygulama Gezilerinden Beklentilerinin ve Memnuniyet Düzeylerinin Araştırılması / Investigation of Tourist Guide Candidates' Expectations and Satisfaction Levels 